\title{
Implementation of Dimer-based Screening System in Escherichia coli BL21(DE3) for Selection of Actinomycetes Compounds as Anti- HIV Candidate
}

\author{
Kenia Permata Sukma, Putri Cahya Destiani, Azzania Fibriani* \\ Department of Biotechnology, School of Life Sciences and Technology, Institut Teknologi Bandung, Bandung, Indonesia
}

\section{ARTICLE INFO}

Article history:

Received August 25, 2020

Received in revised form September 30, 2021

Accepted October 28, 2021

\section{KEYWORDS:}

actinomycetes,

anti-HIV,

dimer-based screening system,

HIV,

protease inhibitor

\begin{abstract}
Actinomycetes are reported to have inhibitory activity against several types of Human Immunodeficiency Virus proteases, enzyme with major role in the process of maturation of the virus thus it can infect new cells. Therefore, exploration of Indonesia's actinomycetes species is expected to be a breakthrough for HIV treatment. In this study, selection of anti-HIV candidate compounds was conducted using a dimer-based screening system on recombinant Escherichia coli BL21(DE3). The construct includes the fusion of the AraC DNA binding domain + $\mathrm{HIV}-1$ protease as the regulator and the green fluorescence protein as the reporter. Confirmation of the plasmid construct was carried out by PCR which showed size of $\sim 1,076 \mathrm{bp}$. Sequencing analysis proved $100 \%$ similarity and identity between construct used in this study and one previously designed. SDS-PAGE showed the presence of band in the size of $\sim 24 \mathrm{kDa}$ equal to the size of the fusion protein. Compounds BLH 1-12 (2) EA, MAE 1-13 EA, BLH 1-1 EA, BLH 7-5 MetA, LC 98 (1) EA, exhibited consistent and significant protease-HIV inhibitory activity at certain concentrations. Thus, in this study, dimer-based screening system is considered to be able to detect actinomycetes as a new anti-HIV candidate for the protease inhibitor group.
\end{abstract}

\section{Introduction}

Human Immunodeficiency Virus (HIV) is a virus which damages cells in the immune system and weakens the body's ability to fight infection and disease. The disease caused by HIV is called Acquired Immune Deficiency Syndrome (AIDS), a potentially life-threatening infection that occurs when the immune system has been damaged by the HIV virus. To this day, there has been no drug to cure HIV, but various drugs have effectively allowed sufferers to survive (NHS 2018). The number of HIV sufferers in the world in 2018 was recorded at \pm 37.9 million, with a death rate of 770 thousand people (UNAIDS 2018). In Indonesia alone in 2016 there were \pm 630 thousand HIV sufferers, \pm 49 thousand new sufferers, and \pm 39 thousand HIV-related deaths with a prevalence rate of $0.4 \%$ (UNAIDS 2017).

Treatment of HIV sufferers is currently carried out using antiretroviral therapy (ART) which involves more than 25 types of drugs divided into 6 different

\footnotetext{
* Corresponding Author

E-mail Address: afibriani@sith.itb.ac.id
}

classes. The six classes are NRTI (Nucleoside/ Nucleotide Reverse Transcriptase Inhibitor), NNRTI (Non-nucleoside Reverse Transcriptase Inhibitor), PI (Protease Inhibitor), INSTI (Integrase Inhibitor), FI (Fusion Inhibitor), and CCR5 antagonists (C-C Chemokine Receptor 5) (Eggleton and Nagalli 2020). The research by Mathis et al. (2011) proved that therapy using protease inhibitor class drugs alone (protease inhibitor monotherapy) can reduce amount of virus in patients so that they do not need to undergo treatment using the ART method with two stages of treatment. Research by Oddershede et al. (2016) and Paton et al. (2016) also concluded that the protease inhibitor monotherapy method was more efficient compared to ongoing triple therapy (OT) in HIV patients who already had low virus counts due to pressure from triple therapy done.

In previous studies, a dimer-based screening system (DBSS) in Escherichia coli BL21(DE3) is applied to identify compounds that could inhibit HIV-1 protease inhibitors (Dwipayana 2018) using a construct designed by Fibriani et al. (2018), adapted from a system for screening new antitubercular drugs designed by Rahmita (2015) and patented under 
patent number P00201704939 on behalf of inventors Giri-Rachman et al. (2017) which was also adapted from research by Furuta et al. (2005) and Okada et al. (2007). The selection of these compounds aims to find alternatives to protease inhibitors other than those commonly used in therapy, such as darunavir because the price is still relatively expensive. The DBSS construct that was also used in this study contained a diffused HIV-1 protease base sequence with the $\mathrm{AraC}$ protein base sequence in the DNA binding domain (DBD AraC). AraC protein can bind to the $\mathrm{AraC}$ promoter sequence and inhibit its transcription, so that the activation of the promoter can be detected due to the presence of the reporting gene at the downstream promoter, namely Emerald Green Fluorescence Protein (EmGFP) (Okada et al. 2007; Steven 2017; Fibriani et al. 2018). In this study, we aim to identify the potential actinomycetes for
anti-HIV candidates using the DBSS method in E. coli BL21(DE3).

\section{Materials and Methods}

This research was conducted at the Genetics and Molecular Biotechnology Laboratory and Instrumentation I Laboratory of School of Life Sciences and Technology Building, also at the Nanobiology Laboratory of Center for Advanced Sciences (CAS) Building, Institut Teknlogi Bandung. The research started in February 2019 to April 2020 for 1 year and 2 months. The samples of actinomycetes compounds used in this study were obtained from Indonesian Institute of Sciences (LIPI) as a research partner. An illustration of how the DBSS system works in E. coli BL21(DE3) is shown in Figure 1.

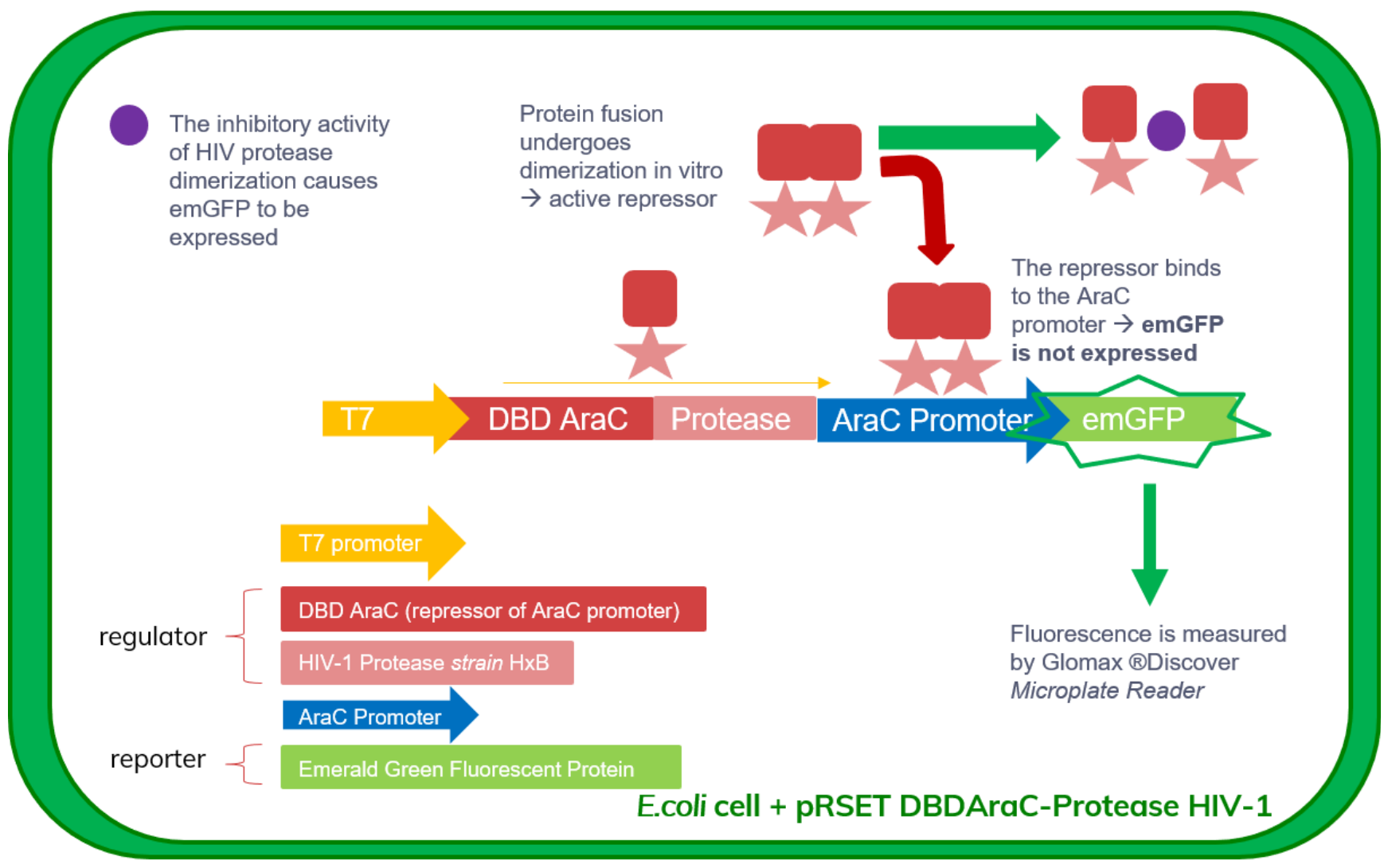

Figure 1. Illustration of the mechanism of the DBSS system (pHxB-DBD AraC protein fusion) in E. coli BL21(DE3) 


\subsection{Culture Rejuvenation}

Culture of E. coli BL21(DE3) without construct, as well as E. coli BL21(DE3) containing pRSET DBDAraCProtease HIV-1 and pRSET DBDAraC construct, were rejuvenated first. E. coli BL21(DE3) culture without the construct would be used as a negative control, while the culture containing the pRSET DBDAraC construct would be used as a positive control for cultures with the DBSS construct which would be treated with various actinomycetes compounds in the screening activity. Culture rejuvenation was carried out by inoculating the culture from glycerol stock or from LB agar media followed by incubation for 16 hours at $37^{\circ} \mathrm{C}$.

\subsection{Confirmation of the PRSET DBDAraC- Protease HIV-1 Construct}

Confirmation of the pRSET DBDAraC-Protease HIV-1 construct in culture began with colony PCR using 2 primers, forward primer "DBDAraC" which binds to the upstream region of the $\mathrm{AraC}$ gene and the reverse primer "AraCpromoter" which binds to the downstream region of the $\mathrm{AraC}$ promoter. For sequencing analysis, the primers used are the same as those for PCR. From the raw data of the sequencing results, trimming was carried out, followed by contig using Bioedit software to form a sequence consensus. The consensus of the sequences is seen by their suitability with alignment using the pairwise alignment tool in the EMBOSS Water software (Madeira 2019).

\subsection{Confirmation of $\mathrm{pHxB}-\mathrm{DBDA}$ ac Protein Expression}

Confirmation with SDS-PAGE was carried out to confirm the expression of the pHxB-DBDAraC fusion protein on E. coli BL21(DE3) containing the plasmid construct. The concentrations of stacking gel and separating gel used were $5.0 \%$ and $12.5 \%$, respectively, with a condition of $100 \mathrm{~V}$ and $25 \mathrm{~mA}$ per gel for \pm 150 minutes. The lysate sample load was added as much as $10 \mu$, while the load of the pellet sample was added as much as $2 \mu$ l. When finished, the gel is soaked in a staining buffer for 2-3 hours, then with deion overnight for the destaining. The gel finally can be observed visually or with the help of an observation light device.

\subsection{Selection of Actinomycetes Compounds}

At this stage, the actinomycetes compound was selected by adding it to the culture of $E$. coli BL21(DE3) containing the PRSET DBDAraC-Protease HIV-1 construct as well as control culture, then measuring the fluorescence of the culture after the treatment. The actinomycetes compounds used can be seen in Table 1 . These compounds have been extracted by LIPI as research partners, using two types of solvents, ethyl acetate and methanol: 1:1 ethyl acetate. The selection of actinomycetes compounds with DBSS consists of 4 stages. First, cultivation by inoculation into solid LB media. Then, activation to liquid LB media, followed by cultivation to liquid LB media with the treatment of actinomycetes compounds at various types of concentrations. Later, fluorescence and optical density (OD) measurements. OD measurements were carried out at a wavelength of $600 \mathrm{~nm}$, while fluorescence measurements were carried out at an excitation wavelength of $475 \mathrm{~nm}$ and an emission wavelength of 500-550 $\mathrm{nm}$.

\subsection{Statistical Analysis}

In this study, a statistical test was carried out using the Mann WhitneyUTest to determine the significance of the difference in the fluorescence score of the samples of each compound at several concentration compared to the baseline. The difference that is considered significant is once the $\mathrm{p}$-value obtained is $\leq 0.05$ and Cohen's Effect Size (ES) d is $\geq 0.8$ (Sullivan and Feinn 2012; Gignac 2019). The statistical Mann Whitney U Test was performed using the IBM SPSS Statistics for Windows software, version 25.0 (IBM Corp., Armonk, N.Y., USA).

Table 1. Actinomycetes compounds used in this study

\begin{tabular}{ll}
\hline Actinomycetes & Compounds code \\
\hline Act 1 & BLH 1-12 (2) EA \\
Act 2 & BLH 5-29 (2) EA \\
Act 3 & LC 69 EA \\
Act 4 & BLH 1-12 (2) MetA \\
Act 5 & BLH 5-29 (2) MetA \\
Act 6 & LC 69 MetA \\
Act 7 & MAE 1-13 EA \\
Act 8 & SHP 2-1 EA \\
Act 9 & SHP 2-1 MetA \\
Act 10 & DHE 5-1 MetA \\
Act 11 & BSE 7F MetA \\
Act 12 & BLH 1-1 MetA \\
Act 13 & BLH 7-5 EA \\
Act 14 & LC 98 (1) MetA \\
Act 15 & BLH 1-1 EA \\
Act 16 & BLH 7-5 MetA \\
Act 17 & LC 98 (1) EA \\
Act 18 & BSE 7F EA \\
Act 19 & DHE 5-1 EA \\
\hline
\end{tabular}




\section{Results}

\subsection{Confirmation of the Size and Sequence of the pRSET DBDAraC-Protease HIV-1 Construct Plasmid Containing the pHxB-DBDAraC Fusion Protein}

E. coli BL21(DE3) as an expression system used in this study was first confirmed to have the DBSS construct plasmid, pRSET DBDAraC-Protease HIV-1. In the plasmid, the fusion of the $\mathrm{pHxB}$-DBDAraC gene and the AraC promoter is flanked by two primary adhering sites, which are the forwardDBDAraC primer (5'CTGGAAAGGATCCATGGATAATCGGGTACGC3') and the reverse AraC promoter (5'CATAGCAG3GCCATG) primer, the same primers used for PCR amplification and sequencing analysis.

The PCR electrophoregram in Figure 2 shows $E$. coli BL21(DE3) used in this study has a fusion protein coding gene pHxB-DBDAraC. This is indicated by the presence of amplicon DNA bands with high intensity in the $1,000 \mathrm{bp}$ region, same with the length of the fusion protein gene, 1,076 bp. The DBSS area in the plasmid sandwiched by primer is shown in Figure 3.

Sequencing analysis was carried out to confirm the sequence of the $\mathrm{pHxB}-\mathrm{DBDAraC}$ fusion protein coding gene sequence with the constructs designed in previous studies. In parallel, this sequencing analysis has been carried out by DBSS research teammates during the study. Pairwise alignment was carried out by comparing the sequence of the construct (sequencing_HxB2) to one belongs to the previous study (design_HxB2). Pairwise alignment is carried out using the Emboss Water tool, and produces a similarity and identity matrix of $100 \%$ between the two, as can be seen in Figure 4. Thus, the E. coli BL21(DE3) culture used in this study was confirmed to have the plasmid pRSET DBDAraC-Protease HIV-1 containing the $\mathrm{pHxB}-\mathrm{DBDAraC}$ fusion protein.

\subsection{Expression of pHxB-DBDAraC Fusion Protein in Escherichia coli BL21(DE3)}

The expression of the pHxB-DBDAraC fusion protein in E. coliBL21(DE3)in this study was confirmed by SDS-PAGE analysis. Samples from E. coli BL21(DE3) containing plasmid pRSET DBDAraC-Protease HIV-1 and E. coli BL21(DE3) without plasmid as negative control, previously sonicated to separate dissolved and insoluble protein fractions. The expression of the fusion protein $\mathrm{pHxB}-\mathrm{DBDAraC}$ on pRSET plasmids in the SDS-PAGE analysis occurred without the need for isopropyl $\beta$-D-1-thiogalactopyranoside (IPTG) induction in the culture process due to "leakage" of the RNA polymerase T7 enzyme expression, which is often found in protein expression using the E. coli
BL21(DE3) expression system. Previous research in culture with plasmid pAraC_PhoRMtb suggested that basal expression occurs under the control of the T7 promoter without IPTG induction. Fusion protein bands from non-induced and induced cultures did not show significant differences in expression so that induction was deemed unnecessary, also because of the toxic nature of IPTG. Thus, in this study, culture, both the plasmid pRSET proteaseHIV1-DBDAraC and pRSET DBDAraC were not induced by IPTG.

The SDS-PAGE confirmation results showed the presence of a protein band with a fairly high intensity at $\sim 25 \mathrm{kDa}$ in E. coli samples with pRSET DBDAraCProtease HIV-1 plasmid, especially in lysates (Figure 5 ). This size is similar to the size of the pHxB-DBDAraC fusion protein, which is $24.2 \mathrm{kDa}$. The expressed fusion protein is considered to be soluble. The presence of $\mathrm{a}$ band showing the expression of $\mathrm{pHxB}$-DBDAraC was not observed in samples from E. coli BL21(DE3) without plasmid. Thus, in this study the culture of E. coli BL21(DE3) with the plasmid pRSET DBDAraCProtease HIV-1 was considered successfully express the DBSS fusion protein.

\subsection{Selection of HIV-1 Protease Dimerization Actinomycetes Compounds with Dimer-based Screening System}

The selection of actinomycetes compounds was carried out using the DBSS method to identify the inhibitory activity of HIV-1 protease dimerization in the $\mathrm{pHxB}-\mathrm{DBDAraC}$ fusion protein. Indication of protease dimer inhibitory activity was observed based on the expression of fluorescence protein emGFP as a reporting gene in the downstream part of the construct. The treatment scheme of actinomycetes compounds to the $E$. coli containing the DBSS construct on the screening is shown in Figure 6. In 19 types of tested actinomycetes compounds, each with a treatment of 5 types of concentrations, the results of the fluorescence values read with the Glomax ${ }^{\circledR}$ Discover Microplate Reader are displayed in Table 2. A positive $(+)$ means that the treatment shows an increase in the fluorescence compared to baseline. Meanwhile, the negative (-) means that the fuorescence value shown in the treatment is not greater than the baseline.

Several actinomycetes compounds with certain concentrations showed the fluorescence value which were consistently greater than baseline at 2 repetitions of treatment batches, where each batch involved 5 repetitions. This positive consistency was shown by treatment with Actinomycetes 1 at a concentration of $2 \mathrm{ppm}$ and $6 \mathrm{ppm}$; Actinomycetes 5 at $2 \mathrm{ppm}, 6$ ppm, 8 ppm and 10 ppm; Actinomycetes 6 at 6 ppm; 


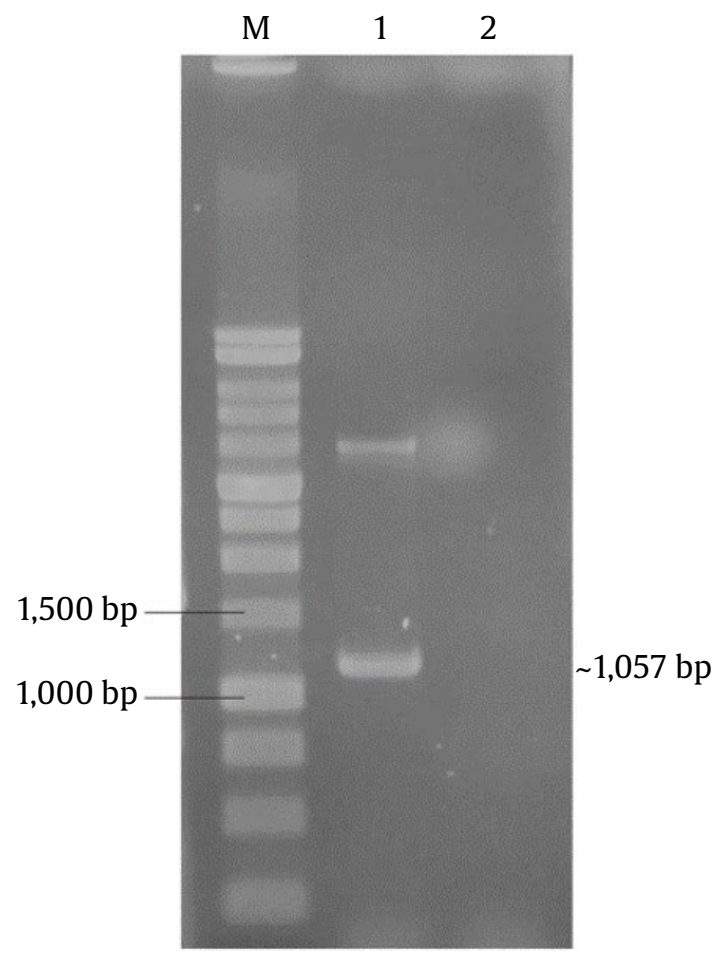

Figure 2. Electrophoregram result of pHxB-DBDAraC PCR confirmation. M: $1 \mathrm{~kb}$ DNA ladder, 1: amplicon of pHxB-DBDAraC gene, 2: negative control of PCR. The results showed that the DNA bands containing pHxB-DBDAraC fusion were confirmed
Actinomycetes 7 at 4 and 10 ppm; Actinomycetes 15 at $8 \mathrm{ppm}$ and $10 \mathrm{ppm}$; Actinomycetes 16 at $2 \mathrm{ppm}$ and $6 \mathrm{ppm}$; and Actinomycetes 17 at $8 \mathrm{ppm}$ and $10 \mathrm{ppm}$. Thus, 7 Actinomycetes compounds were selected at said concentrations.

\subsection{Analysis of Statistical Test Results}

Statistical tests were carried out to determine the significance of the fluorescence value produced by the treatment compared to the baseline. In principle, the p-value aims to determine the probability of similarity between two unpaired samples. Meanwhile Effect Size, such as Cohen's d value, functions to show how different the mean is between the two samples or how much influence the difference could affect, in this case the treatment with compounds is compared to the baseline.

Based on the results shown in Table 3, several compounds were selected at certain concentrations which in addition to being consistently positive, also showed differences in fluorescence values which were statistically significant different from those of the baseline. The compounds were Actinomycetes 1 at $6 \mathrm{ppm}$; Actinomycetes 7 at $4 \mathrm{ppm}$ and 10 ppm; Actinomycetes 15 at $8 \mathrm{ppm}$ and $10 \mathrm{ppm}$; Actinomycetes 16 at $2 \mathrm{ppm}$; and Actinomycetes 17 at $8 \mathrm{ppm}$. Therefore, 6 Actinomycetes compounds

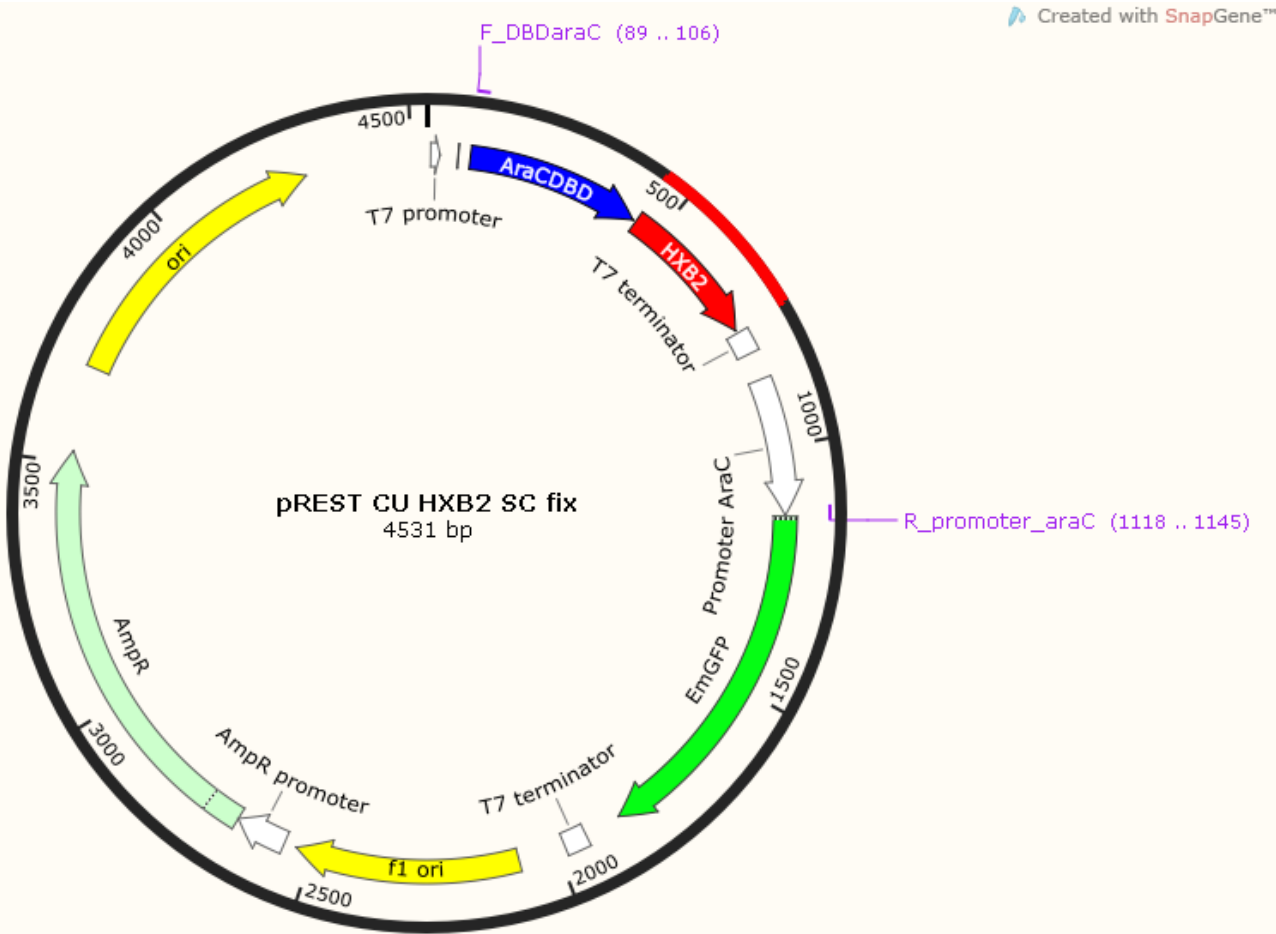

Figure 3. Map of the plasmid with primers site used in this study 


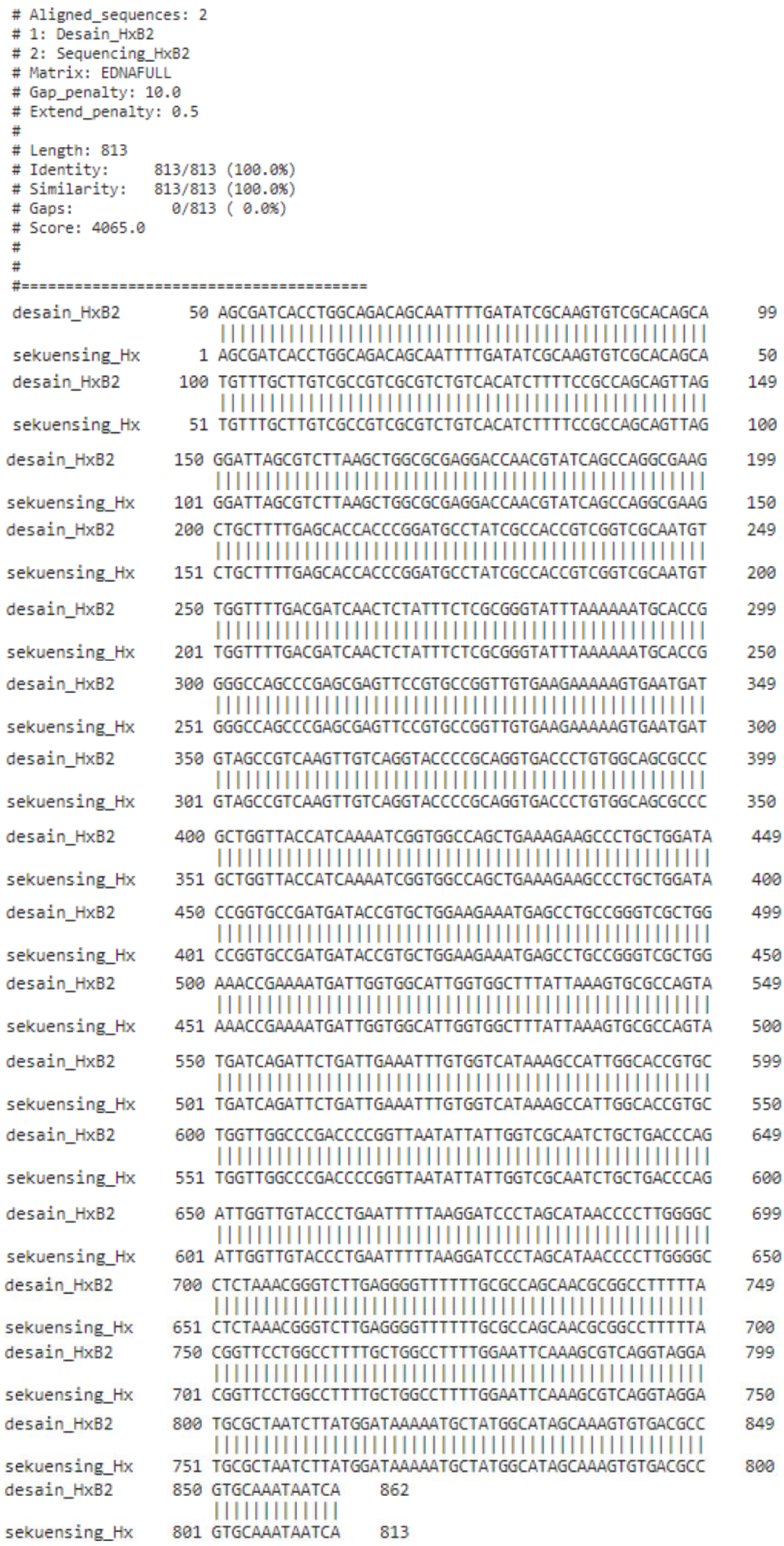

Figure 4. Alignment of the DNA sequence from the sequencing result (sekuensing_HxB2) with the reference design (desain_HxB2). The results show that the two sequences are identical (Tsurayya 2019) 


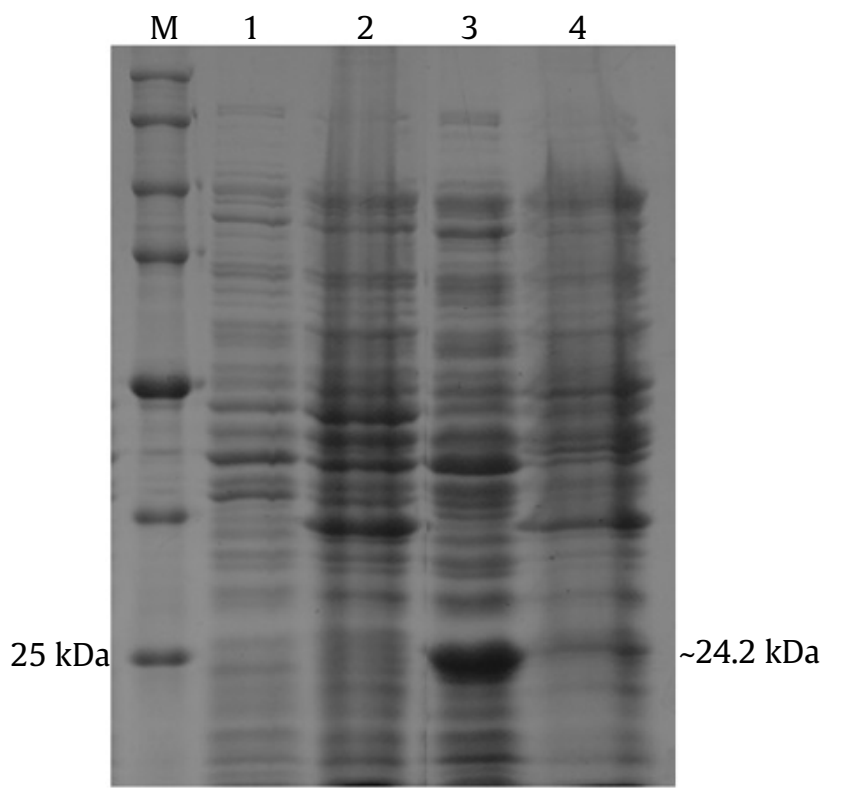

Figure 5. SDS-PAGE electropherogram sample of $E$. coli BL21(DE3) containing pRSET DBDAraC-Protease HIV-1 plasmid and E. coli BL21(DE3) without plasmid as control. M: protein ladder, 1: lysate sample of E. coli BL21(DE3) without plasmid, 2: pellet sample of $E$. coli BL21(DE3) without plasmid, 3: lysate sample of E. coli BL21(DE3) containing DBSS plasmid, 4: pellet sample of E. coli BL21(DE3) containing DBSS plasmid. The results showed that the expression of $\mathrm{pHxB}-$ DBDAraC fusion protein was confirmed in culture, and the protein expressed was suspected to be soluble were selected at certain concentrations that showed consistency and significance of fluorescence values higher than the baseline (marked with asterisk ${ }^{\prime * \prime}$ as shown in Figures 7-9). The three graphs are the result of the average fluorescence value in 2 batches of duplo treatments, in which 5 repetitions of each batch were carried out, then the data were normalized based on the calculation of standard deviation. The error bar on the graph shows the standard deviation value for each of these treatments. The concentrations and compounds that were not selected (did not show consistently and significantly higher fluorescence values than baseline) in the same treatment batch were still presented as comparisons. The baseline fluorescence value is indicated by a red bar which is a culture without the addition of actinomycetes compound and only added with DMSO as a solvent. In addition, a positive control shown by a green bar, which is a culture with plasmids without protease fusion. This positive control serves to ensure that the emGFP in almost the same plasmid system, with the same promoter, can express the emGFP protein well, so that the positive control shows a fluorescence value that may be much higher but is not used as a reference for comparing the fluorescence value in the treatment.

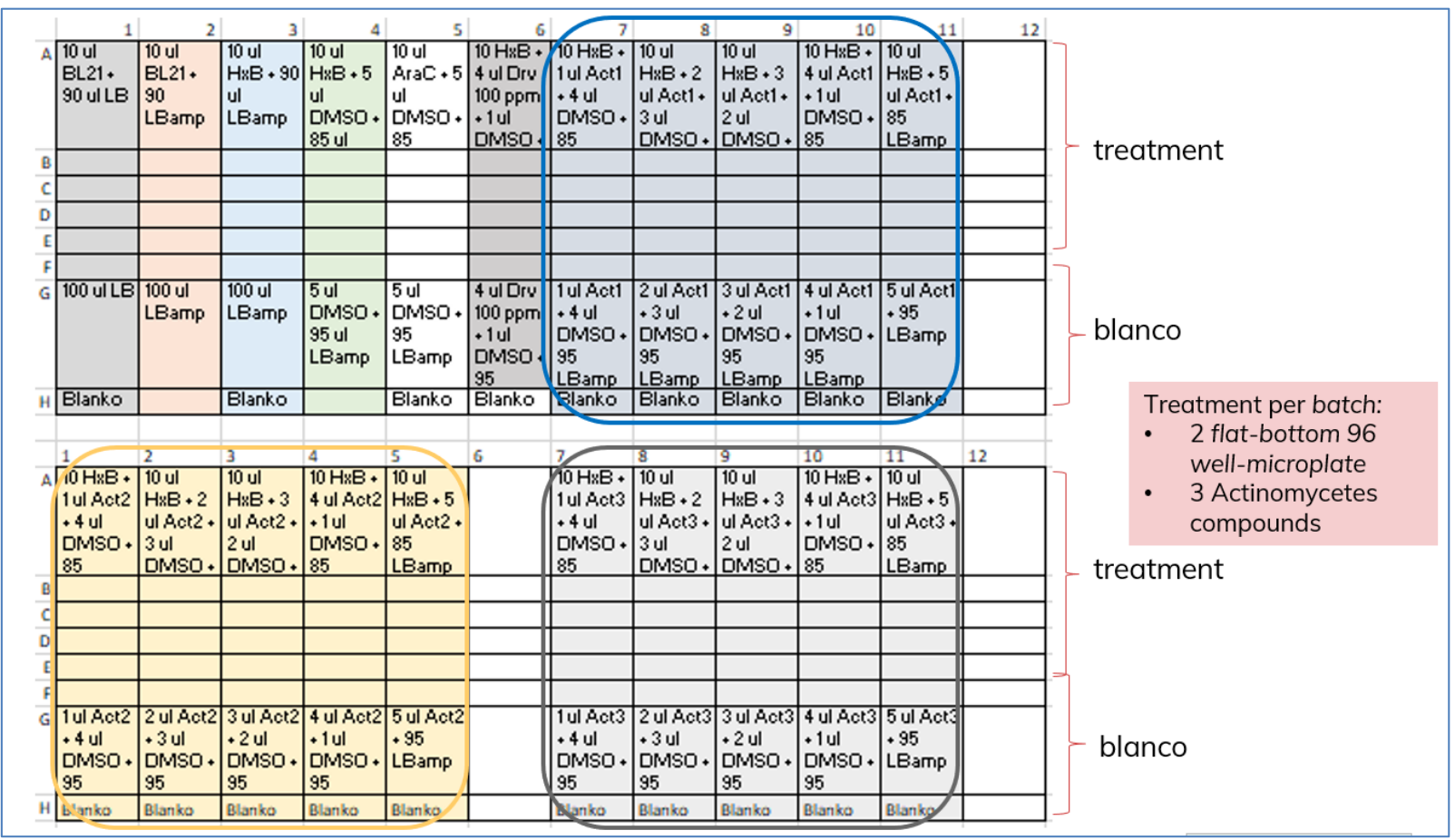

Figure 6. Scheme of actinomycetes compound screening in E. coli containing DBSS construct 
Table 2. The result of actinomycetes compound selection using the DBSS method. (+): the expression of emGFP fluoresecence is relatively greater than baseline; (-): expression of emGFP fluoresecence is relatively smaller than baseline. Seven actinomycetes compounds that were consistently positive at certain concentrations were chosen

\begin{tabular}{|c|c|c|c|c|c|c|c|c|c|c|}
\hline \multicolumn{11}{|c|}{ The result of Actinomycetes screening using DBSS method } \\
\hline \multirow{3}{*}{$\begin{array}{l}\text { Compounds } \\
\text { tested }\end{array}$} & \multicolumn{10}{|c|}{ Concentration } \\
\hline & \multicolumn{2}{|c|}{$2 \mathrm{ppm}$} & \multicolumn{2}{|c|}{$4 \mathrm{ppm}$} & \multicolumn{2}{|c|}{$6 \mathrm{ppm}$} & \multicolumn{2}{|c|}{$8 \mathrm{ppm}$} & \multicolumn{2}{|c|}{$10 \mathrm{ppm}$} \\
\hline & Batch 1 & Batch 2 & Batch 1 & Batch 2 & Batch 1 & Batch 2 & Batch 1 & Batch 2 & Batch 1 & Batch 2 \\
\hline Act 1 & + & + & - & - & + & + & - & - & + & - \\
\hline Act 2 & - & + & - & - & - & - & - & - & - & - \\
\hline Act 3 & - & - & - & + & - & - & - & - & - & - \\
\hline Act 4 & - & - & - & - & - & - & - & - & - & - \\
\hline Act 5 & + & + & + & - & + & + & + & + & + & + \\
\hline Act 6 & + & - & - & + & + & + & - & - & - & - \\
\hline Act 7 & - & + & + & + & - & + & - & + & + & + \\
\hline Act 8 & - & - & - & - & - & - & - & - & - & - \\
\hline Act 9 & + & - & + & - & - & - & - & - & + & - \\
\hline Act 10 & - & - & - & - & - & - & - & - & - & - \\
\hline Act 11 & + & - & + & - & + & - & + & - & + & - \\
\hline Act 12 & - & + & - & + & - & + & - & + & - & - \\
\hline Act 13 & - & - & - & - & - & - & - & - & - & + \\
\hline Act 14 & - & - & - & - & - & - & - & - & - & - \\
\hline Act 15 & + & - & + & - & + & - & + & + & + & + \\
\hline Act 16 & + & + & - & + & + & + & - & + & - & + \\
\hline Act 17 & - & + & + & - & + & - & + & + & + & + \\
\hline Act 18 & - & - & - & - & - & - & - & - & - & - \\
\hline Act 19 & - & - & - & - & - & - & - & - & - & - \\
\hline
\end{tabular}

Table 3. The results of the treatment significance test based on statistical parameters of p-value and effect size (Cohen's d). Effect Size Cohen's d category L: large effect, M: medium effect, S: small effect. Chosen significance value are for $\mathrm{p} \leq 0.05$ and $\mathrm{d} \geq 0.8$ (Lee 2016). Six compounds were chosen at a certain concentration based on the results of the significance of the fluorescence value of the treatment compared to the baseline

\begin{tabular}{|c|c|c|c|c|c|c|c|c|c|}
\hline Compounds & $\mathrm{Z}$ & N1 & $\mathrm{N} 2$ & 1/N1 & $1 / \mathrm{N} 2$ & $\mathrm{p}$ & $\mathrm{d}$ & ES & Significance \\
\hline Act1(2ppm) & 0.577 & 4 & 4 & 0.25 & 0.25 & 0.564 & 0.408001 & $\mathrm{M}$ & \\
\hline $\operatorname{Act} 1(2 \mathrm{ppm})$ & 1.155 & 4 & 4 & 0.25 & 0.25 & 0.248 & 0.816708 & $\mathrm{~L}$ & \\
\hline Act1(6ppm) & 1.732 & 4 & 4 & 0.25 & 0.25 & 0.083 & 1.224709 & $\mathrm{~L}$ & \\
\hline Act1(6ppm) & 2.309 & 4 & 4 & 0.25 & 0.25 & 0.021 & 1.63271 & $\mathrm{~L}$ & $\sqrt{ }$ \\
\hline Act5(2ppm) & 1.414 & 4 & 3 & 0.25 & 0.333333 & 0.157 & 1.07996 & $\mathrm{~L}$ & \\
\hline Act5(2ppm) & 0.707 & 4 & 3 & 0.25 & 0.333333 & 0.480 & 0.53998 & M & \\
\hline Act5(6ppm) & 1.732 & 4 & 4 & 0.25 & 0.25 & 0.083 & 1.224709 & $\mathrm{~L}$ & \\
\hline Act5(6ppm) & 0.000 & 4 & 3 & 0.25 & 0.333333 & 1.000 & 0 & $S$ & \\
\hline Act5(8ppm) & 0.354 & 4 & 3 & 0.25 & 0.333333 & 0.724 & 0.270372 & $\mathrm{~S}$ & \\
\hline Act5(8ppm) & 0.866 & 4 & 4 & 0.25 & 0.25 & 0.386 & 0.612354 & M & \\
\hline Act5(10ppm) & 0.354 & 4 & 3 & 0.25 & 0.333333 & 0.724 & 0.270372 & $\mathrm{~S}$ & \\
\hline Act5(10ppm) & 0.289 & 4 & 4 & 0.25 & 0.25 & 0.773 & 0.204354 & $\mathrm{~S}$ & \\
\hline Act6 $(6 \mathrm{ppm})$ & 0.577 & 4 & 4 & 0.25 & 0.25 & 0.564 & 0.408001 & M & \\
\hline Act6(6ppm) & 0.354 & 4 & 4 & 0.25 & 0.25 & 0.724 & 0.250316 & $\mathrm{~S}$ & \\
\hline Act7(4ppm) & 0.218 & 3 & 4 & 0.333333 & 0.25 & 0.827 & 0.1665 & M & \\
\hline Act7(4ppm) & 2.121 & 4 & 4 & 0.25 & 0.25 & 0.034 & 1.499773 & $\mathrm{~L}$ & $\sqrt{ }$ \\
\hline Act $7(10 \mathrm{ppm})$ & 0.707 & 4 & 4 & 0.25 & 0.25 & 0.480 & 0.499924 & $S$ & \\
\hline Act7 (10ppm) & 2.121 & 4 & 3 & 0.25 & 0.333333 & 0.034 & 1.619941 & $\mathrm{~L}$ & $\sqrt{ }$ \\
\hline Act 15 (8ppm) & 2.121 & 3 & 4 & 0.333333 & 0.25 & 0.034 & 1.619941 & $\mathrm{~L}$ & r \\
\hline Act15(8ppm) & 0.707 & 4 & 4 & 0.25 & 0.25 & 0.480 & 0.499924 & M & \\
\hline Act 15 (10ppm) & 1.964 & 3 & 4 & 0.333333 & 0.25 & 0.050 & 1.50003 & $\mathrm{~L}$ & $\sqrt{ }$ \\
\hline Act15(10ppm) & 1.061 & 4 & 4 & 0.25 & 0.25 & 0.289 & 0.75024 & M & \\
\hline Act16(2ppm) & 0.000 & 3 & 4 & 0.333333 & 0.25 & 1.000 & 0 & $\mathrm{~S}$ & \\
\hline Act16(2ppm) & 2.021 & 4 & 4 & 0.25 & 0.25 & 0.043 & 1.429063 & $\mathrm{~L}$ & $\sqrt{ }$ \\
\hline Act16(6ppm) & 0.513 & 3 & 4 & 0.333333 & 0.25 & 0.513 & 0.39181 & S & \\
\hline Act16(6ppm) & 0.355 & 4 & 4 & 0.25 & 0.25 & 0.355 & 0.251023 & $S$ & \\
\hline Act17 (8ppm) & 1.964 & 3 & 4 & 0.333333 & 0.25 & 0.050 & 1.50003 & $\mathrm{~L}$ & $\sqrt{ }$ \\
\hline Act17(8ppm) & 1.061 & 4 & 4 & 0.25 & 0.25 & 0.289 & 0.75024 & $\mathrm{M}$ & \\
\hline Act 17 (10ppm) & 0.218 & 3 & 4 & 0.333333 & 0.25 & 0.827 & 0.1665 & $\mathrm{~S}$ & \\
\hline Act17(10ppm) & 1.414 & 4 & 4 & 0.25 & 0.25 & 0.157 & 0.999849 & $\mathrm{~L}$ & \\
\hline
\end{tabular}




\section{Corrected Mean Fluorescence Actinomycetes 1-3}

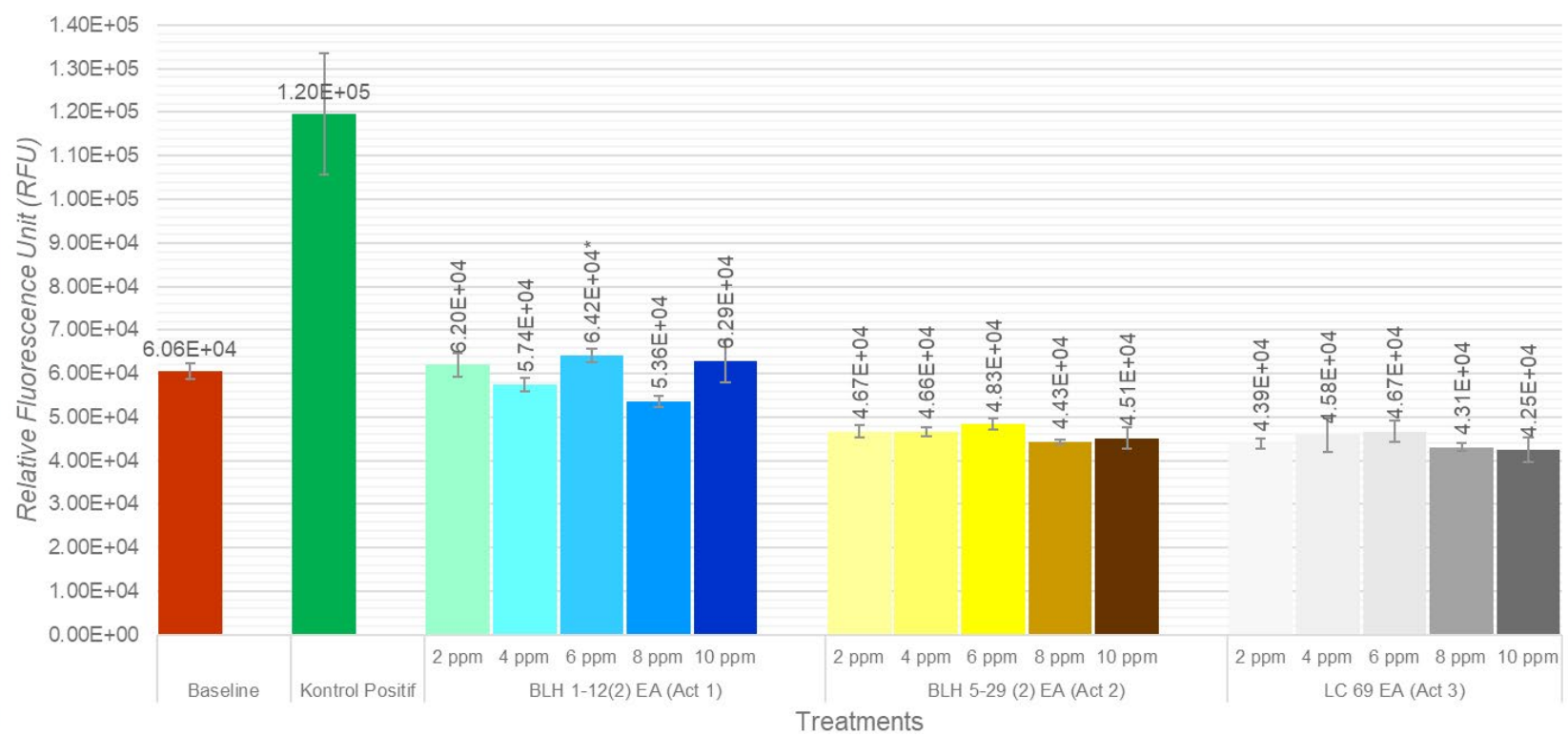

Figure 7. Graph of fluorescence of the culture after Actinomycetes 1-3 treatment. The treatment of Actinomycetes 1 (BLH 1-12(2) EA) at 6 ppm concentration consistently and significantly exhibit a higher fluorescence than the baseline, marked with an asterisk "**"

Corrected Mean Fluorescence Actinomycetes 7-9

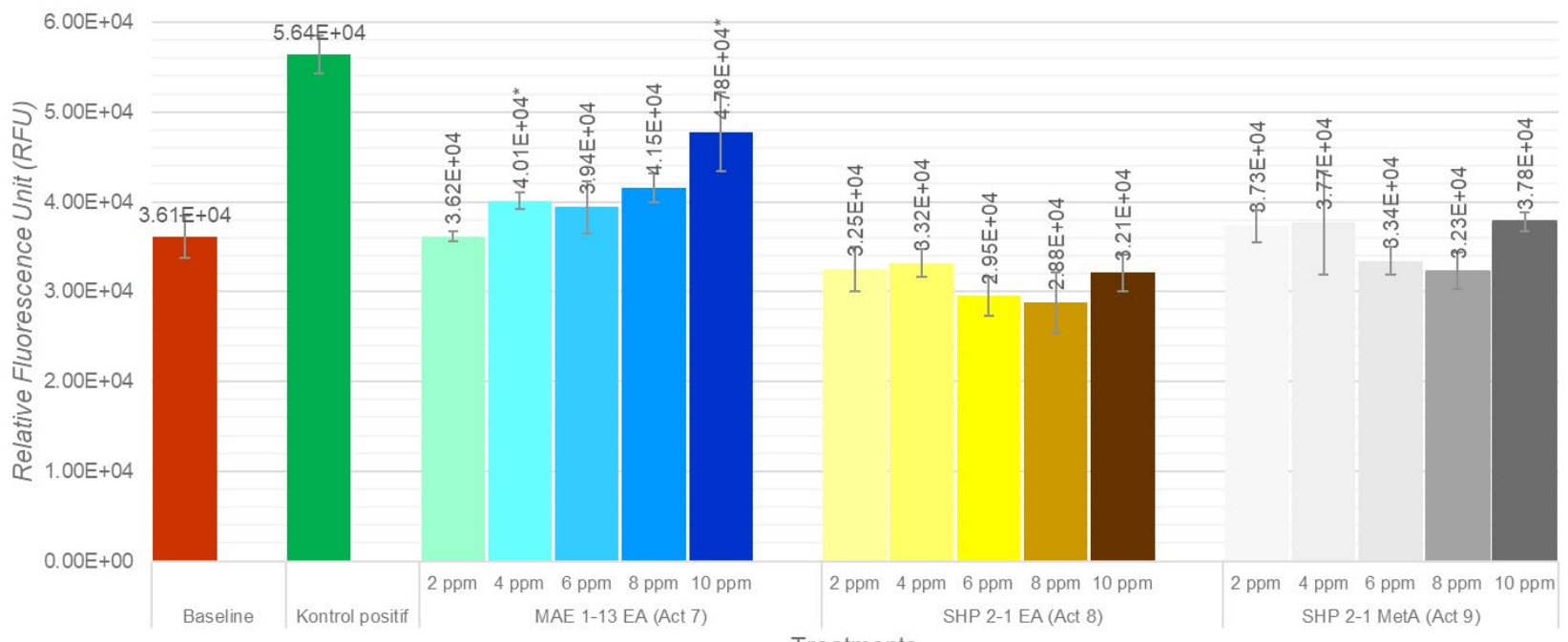

$\mathrm{OD}=0.3-0.4$

Treatments

Figure 8. Graph of fluorescence of the culture after Actinomycetes 7-9 treatment. The treatment of Actinomycetes 7 (MAE $1-13 \mathrm{EA})$ at 4 and $10 \mathrm{ppm}$ concentration consistently and significantly exhibit a higher fluorescence than the baseline, marked with an asterisk “*” 


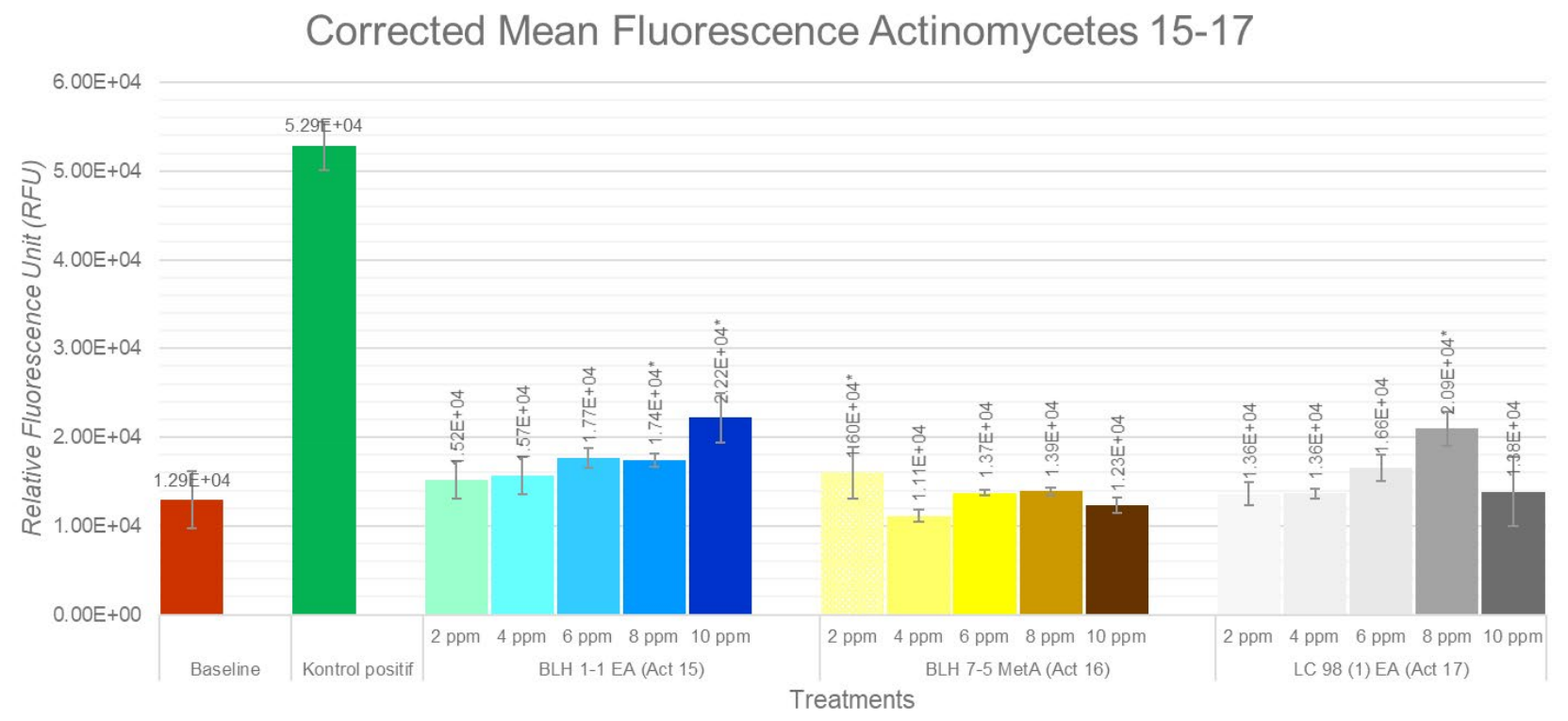

Figure 9. Graph of fluorescence of the culture after Actinomycetes 15-17 treatment. The treatment of Actinomycetes 15 (BLH 1-1 EA) at 8 and $10 \mathrm{ppm}$ concentration, Actinomycetes 16 (BLH 7-5 MetA) at $2 \mathrm{ppm}$ concentration, and Actinomycetes 17 (LC 98(1) EA) at 8 ppm concentration consistently and significantly exhibit a higher fluorescence than the baseline, marked with an asterisk "**.

\section{Discussion}

Although certain concentrations of actinomycetes show a consistently higher increase in fluorescence values and significantly different from the baseline, it can be seen that, the trend based on concentration (dose-dependent) in the selected compounds Actinomycetes $1,7,15,16$ and 17, were not seen in all compounds (Figure 7-9). In compound 1, the fluorescence trend tends to be stable, not experiencing an upward trend. A concentration of $6 \mathrm{ppm}$ showed the highest fluorescence value, followed by a concentration of $10 \mathrm{ppm}$. Likewise with compound 16 which instead showed a decreasing trend of fluorescence as the concentration of the compound increased. Compound 17 shows an increasing trend of emGFP expression according to the concentration but has a slight decrease at the concentration of $10 \mathrm{ppm}$. As for compounds 7 and 15, the fluorescence trend tends to increase, which means that the expression of emGFP is considered to increase along with the increase in compound concentration. In addition, from this phenomenon, it can be observed that 2 compounds whose consistency and significance are represented by 2 concentration points, compounds 7 and 15 where compound 7 is at a concentration of 4 and $10 \mathrm{ppm}$ (Figure 8), while compound 15 at concentrations of 8 and $10 \mathrm{ppm}$ (Figure 9), as can be seen by the asterisk ${ }^{* \prime}$ on the bar graph, also shows an increase in fluorescence expression based on concentration.
As for other compounds which were not observed to show a dose-dependent trend it might occur because of several possibilities. First, the E. coli expression system which still has limitations may cause the fusion of HIV protease with DBDAraC to experience several variations in the fusion protein folding conformation which causes misfolding so that some HIV proteases cannot interact with actinomycetes compounds. The same thing related to the expression of HIV protease in E. coli, it was reported that the protein folding failure was due to misfolding and forming inclusion bodies (Cheng et al. 1990). This phenomenon will have an impact on the appearance of false negatives because the protease fusion dimers that are structurally formed will be mixed with the proteases that have been misfolded, so that the fluorescence expression can still occur but randomly. The formation of inclusion bodies and expression of inactive proteins is a frequent occurrence and is a limitation of the recombinant protein expression system in E. coli (Rosano and Ceccarelli 2014). Second, the availability of solvents in the media can be reduced due to the evaporation during cultivation, this could be quite an impact considering the small working volume of DBSS selection in the microplate, which is only $100 \mu$ l, causing the treatment to be sensitive to even the slightest error. This is also why the comparison of fluorescence values in different batches cannot be compared, and comparisons can only be made against the baseline in the same batch. Third, the extract obtained with ethyl acetate 
and methanol: ethyl acetate 1:1 solvents in the actinomycetes compounds used in this study might allows the dissolved compound to be more than 1 type and has different solubility properties so that the concentration that allows the compound to enter the cell optimally, is also varies.

Even so, several compounds, such as Actinomycetes 7 and 15 showed fluorescence values which showed an increasing trend with increasing concentration. Thus, further exploration of these compounds are expected to provide answers to several emerging phenomena.

Based on this study, the actinomycetes compounds that are recommended to be further explored and considered to have the potential to inhibit HIV protease dimerization are Actinomycetes 1 (BLH 1-12 (2) EA), Actinomycetes 7 (MAE 1-13 EA), Actinomycetes 15 (BLH 1-1 EA), Actinomycetes 16 (BLH 7-5 MetA), and Actinomycetes 17 (LC 98 (1) EA). Molecular docking analysis can also be carried out in future studies to determine the interaction between the test Actinomycetes compounds and pHxB-DBDAraC fusion on the plasmid constructs DBSS, pRSET DBDAraC-Protease HIV-1.

In conclusion, based on the selection with the Dimer-based Screening System (DBSS) method, there are several actinomycetes compounds that are considered to have inhibitory activity of HIV protease dimerization and have the potential to be a new antiHIV candidate for the Protease Inhibitor (PI) class, namely BLH 1-12 (2) EA, MAE 1-13 EA, BLH 1-1 EA, BLH 7-5 MetA, and LC 98 (1) EA. The next research step is further exploration of the content of actinomycetes compounds and molecular docking analysis to determine the interaction between actinomycetes compounds and DBSS construct fusion proteins.

\section{Acknowledgements}

The study was financially supported by the Ministry of Research, Technology and Higher Education of the Republic of Indonesia. The Indonesian Institute of Sciences (LIPI) contributed in this study to providing Actinomycetes isolates and extracting active compounds from the isolates.

\section{References}

Cheng, Y.S., McGowan, M.H., Kettner, C.A., Schloss, J.V., Erickson-Viitanen, S., Yin, F.H., 1990. High-level synthesis of recombinant HIV-1 protease and the recovery of active enzyme from inclusion bodies. Gene. 87, 243-248. https://doi.org/10.1016/03781119(90)90308-E
Dwipayana, I.D.A.P., 2018. Pengembangan dan pengujian sistem seleksi senyawa penghambat pembentukan dimer protease HIV-1 [Essay] Bandung, Indonesia: Institut Teknologi Bandung.

Eggleton, J.S., Nagalli, S., 2020. Highly Active Antiretroviral Therapy (HAART). StatPearls Publishing, Florida. http://www.ncbi.nlm.nih.gov/books/NBK554533/

Fibriani, A., Feraliana, Steven, N., Rahmita, M., Rachman, E.G., 2018. Plasmid construction for development of a high throughput system selection of new antiHIV drugs derived from biological resources from Indonesia. Biotechnol Ind J. 14, 166.

Furuta, E., Yamamoto, K., Tatebe, D., Watabe, K., Kitayama, T., Utsumi, R., 2005. Targeting protein homodimerization: a novel drug discovery system. FEBS Lett. 579, 2065-2070. https://doi.org/10.1016/j. febslet.2005.02.056

Gignac, G.E., 2019. How2statsbook. Online first ed. Perth. pp. 1-47. Available at: http://www.how2statsbook. com/p/about.html. [Date accessed: 27 November 2018]

Giri-Rachman, E.A., Fibriani, A., Rahmita, M., Steven, N., 2017. Produk bakteri Escherichia coli yang dimodifikasi secara genetik untuk penapisan cepat kandidat obat antituberkulosis baru. Indonesian Patent Application No. ID/P00201704939. blob:https:// pdki-indonesia.dgip.go.id/b73b62ca-1ead-48f58314-0387c94a6706.

Lee,D.K.,2016.AlternativestoPvalue:confidenceintervaland effect size. Korean Journal of Anesthesiology. 69, 555562. https://doi.org/10.4097/kjae.2016.69.6.555

Madeira,F.,Park, Y.M.,Lee,J.,Buso,N.,Gur,T.,Madhusoodanan, N., Basutkar, P., Tivey, A.R.N., Potter, S.C., Finn, R.D., Lopez, R., 2019. The EMBL-EBI search and sequence analysis tools APIs in 2019. Nucleic Acids Research. 47, 636-641. https://doi.org/10.1093/nar/gkz268

Mathis, S., Khanlari, B., Pulido, F., Schechter, M., Negredo, E., Nelson, M., Vernazza, P., Cahn, P., Meynard, J.L., Arribas, J., Bucher, H.C., 2011. Effectiveness of protease inhibitor monotherapy versus combination antiretroviral maintenance therapy: a meta-analysis. PLoS One. 6, e22003. https://doi.org/10.1371/journal. pone.0022003

[NHS] National Health Service., 2018. HIV and AIDS. Available at: https://www.nhs.uk/conditions/hivand-aids/. [Date accessed: 27 November 2018]

Oddershede, L., Walker, S., Stöhr, W., Dunn, D.T., ArenasPinto, A., Paton, N.I., Sculpher, M., 2016. Protease inhibitor monotherapy versus ongoing triple therapy (pivot) trial team. Cost effectiveness of protease inhibitor monotherapy versus standard triple therapy in the long-term management of HIV patients: analysis using evidence from the pivot trial. Pharmacoeconomics 34, 795-804. https://doi. org/10.1007/s40273-016-0396-X 
Okada, A., Gotoh, Y., Watanabe, T., Furuta, E., Yamamoto, K., Utsumi, R., 2007. Targeting two-component signal transduction: a novel drug discovery system. Methods in Enzimology. 422, 386-395. https://doi. org/10.1016/S0076-6879(06)22019-6

Paton, N.I., Stöhr, W., Oddershede, L., Arenas-Pinto, A., Walker,S.,Sculpher, M.,Dunn, D.T.,2016. The protease inhibitor monotherapy versus ongoing triple therapy (pivot) trial: a randomised controlled trial of a protease inhibitor monotherapy strategy for longterm management of human immunodeficiency virus infection. Health Technol Assess. 20, 1-158. https://doi.org/10.3310/hta20210

Rahmita, M., 2015. Pengembangan sistem penapisan obat antituberkulosis baru dengan target PhoR Mycobacterium tuberculosis $\mathrm{H} 37 \mathrm{Rv}$ menggunakan protein represor AraC Escherichia coli [Thesis]. Bandung, Indonesia: Institut Teknologi Bandung.

Rosano, G.L., Ceccarelli, E.A., 2014. Recombinant protein expression in Escherichia coli: advances and challenges. Front Microbiol. 5, 172. https://doi. org/10.3389/fmicb.2014.00172
Steven, N., 2017. Pengembangan dan pengujian sistem penapisan senyawa organik penghambat pembentukan dimer domain sitoplasmik PhoR Mycobacterium tuberculosis [Thesis]. Bandung, Indonesia: Institut Teknologi Bandung.

Sullivan, G.M., Feinn, R., 2012. Using effect size-or why the $\mathrm{p}$ value is not enough. Journal of Graduate Medical Education. 4, 279-282. https://doi.org/10.4300/ JGME-D-12-00156.1

Tsurayya, N., 2019. Aplikasi dimer-based screening system (DBSS) dalam menyeleksi kandidat obat anti-HIV [Essay]. Bandung, Indonesia: Institut Teknologi Bandung.

[UNAIDS] Joint United Nations Programme on HIV and AIDS., 2017. Country factsheets INDONESIA | 2017. Available at: http://www.unaids.org/en/regionscountries/ countries/indonesia. [Date accessed: 27 November 2018]

[UNAIDS] Joint United Nations Programme on HIV and AIDS., 2018. GLOBAL HIV STATISTICS. Available at: http://www.unaids.org/sites/default/files/media asset/UNAIDS_FactSheet_en.pdf [Date accessed: 27 November 2018] 